\title{
Getting the ecology into interactions between plants and the plant growth-promoting bacterium Pseudomonas fluorescens
}

\section{W. H. Gera Hol*, T. Martijn Bezemer and Arjen Biere}

Department of Terrestrial Ecology, Netherlands Institute of Ecology, Wageningen, Netherlands

Edited by:

Marcel Dicke, Wageningen University, Netherlands

\section{Reviewed by:}

Choong-Min Ryu, Korea Research Institute of Bioscience and Biotechnology, South Korea

Ana Pineda, Wageningen University, Netherlands

\section{*Correspondence:}

W. H. Gera Hol, Department of Terrestrial Ecology, Netherlands Institute of Ecology,

Droevendaalsesteeg 10, 6708 PB

Wageningen, Netherlands.

e-mail: g.hol@nioo.knaw.nl
Plant growth-promoting rhizobacteria (PGPR) are increasingly appreciated for their contributions to primary productivity through promotion of growth and triggering of induced systemic resistance in plants. Here we focus on the beneficial effects of one particular species of PGPR (Pseudomonas fluorescens) on plants through induced plant defense. This model organism has provided much understanding of the underlying molecular mechanisms of PGPR-induced plant defense. However, this knowledge can only be appreciated at full value once we know to what extent these mechanisms also occur under more realistic, species-diverse conditions as are occurring in the plant rhizosphere. To provide the necessary ecological context, we review the literature to compare the effect of $P$. fluorescens on induced plant defense when it is present as a single species or in combination with other soil dwelling species. Specifically, we discuss combinations with other plant mutualists (bacterial or fungal), plant pathogens (bacterial or fungal), bacterivores (nematode or protozoa), and decomposers. Synergistic interactions between $P$. fluorescens and other plant mutualists are much more commonly reported than antagonistic interactions. Recent developments have enabled screenings of $P$. fluorescens genomes for defense traits and this could help with selection of strains with likely positive interactions on biocontrol. However, studies that examine the effects of multiple herbivores, pathogens, or herbivores and pathogens together on the effectiveness of PGPR to induce plant defenses are underrepresented and we are not aware of any study that has examined interactions between P. fluorescens and bacterivores or decomposers. As cooccurring soil organisms can enhance but also reduce the effectiveness of PGPR, a better understanding of the biotic factors modulating $P$. fluorescens-plant interactions will improve the effectiveness of introducing $P$. fluorescens to enhance plant production and defense.

Keywords: PGPR-bacteria, Pseudomonas fluorescens, species interactions, complexity, herbivores, decomposers, bacterivores, mutualists

\section{INTRODUCTION}

Plant growth-promoting rhizobacteria (PGPR) are a diverse group of microorganisms that are increasingly appreciated for their contributions to primary productivity through promotion of growth and triggering of induced systemic resistance (ISR) in plants. By triggering plant defense, PGPR can make an important contribution to biocontrol of pests and pathogens of plants. However, the effectiveness of PGPR-triggered plant defense depends on a variety of genetic and biotic/abiotic environmental factors. PGPR naturally occur within a complex community of soil organisms inhabiting the rhizosphere. Hence, in order to understand the role of PGPR in influencing a plant's defense against pests and pathogens, it is important to understand how biotic interactions with these rhizosphere organisms will affect the ability of PGPR to enhance plant defense. The aim of this review is to examine how the impact of PGPR on plant defense is modulated by the presence of other organisms in the rhizosphere. Other reviews have focused on particular interactions, e.g., between PGPR and aboveground insects (Pieterse and Dicke, 2007; Pineda et al., 2010) or type of defense, e.g., volatiles (Dicke and Baldwin, 2010). Those reviews have taken a plant centric approach (but see Whipps, 2001). In this paper, we will review how biotic interactions between PGPR and other rhizosphere- or plant-associated organisms affect the ability of PGPR to enhance plant defenses. We use Pseudomonas fluorescens, a very common and well-studied PGPR, as a model species. To test the dependence of PGPR-plant interactions on direct and indirect biotic interactions with other rhizosphere biota, we compare studies in which effects of $P$. fluorescens on plant defense are examined for a single $P$. fluorescens isolate with studies in which these effects are examined for a $P$. fluorescens isolate in combination with other isolates and/or species. We will discuss these interactions in increasing order of complexity, starting with single introductions of $P$. fluorescens with introductions of multiple P. fluorescens isolates, then with other PGPR, with other plant growth-promoting fungi, bacterivores, and finally with decomposing organisms. The basic interaction in all these studies is formed by a plant, $P$. fluorescens and a herbivore or pathogen. The latter is necessary to judge whether plant defense was changed. In 
addition, studies without herbivore or pathogens but that measure plant defense genes are included. Before we review these interactions we provide a brief introduction to PGPR and $P$. fluorescens in particular. Moreover, as we argue that the effect of PGPR on induced plant defense cannot be considered in isolation from the effects of other organisms that are also present in the soil such as nematodes, fungi, earthworms, or protozoa on the PGPR or on the plant, we also provide a brief overview of interactions between bacteria and other soil dwelling organisms in the rhizosphere.

\section{INTERACTIONS BETWEEN BACTERIA AND OTHER SOIL ORGANISMS IN THE RHIZOSPHERE}

Live roots and root exudates provide a diverse range of resources to soil organisms. As a result, the zone around plant roots, the rhizosphere, is a highly diverse habitat. It consists of root herbivores, such as nematodes and insect larvae, their natural enemies, and a wide variety of soil microbes, including symbiotic, pathogenic, and saprophytic fungi and protozoa. The vast majority of soil organisms in the rhizosphere are bacteria (including PGPR), with densities as high as $10^{9}$ cells per gram of soil. The abundance and composition of these soil bacteria depends on abiotic conditions such as soil $\mathrm{pH}$, temperature, and moisture (Bardgett, 2005). However, in the rhizosphere of plants, the density and activity of bacteria is fuelled largely by root-derived carbon. Bacteria compete with each other and other soil microorganisms for these carbon resources.

In the rhizosphere, bacteria can have direct beneficial or harmful effects on the plant. However, there are also important indirect feedback interactions between plant roots, soil bacteria, and other microorganisms (Berendsen et al., 2012). For example, root-released exudates promote bacterial growth (Bais et al., 2001). These bacteria are consumed by protozoa and bacterivorous nematodes, and these consumers generally cause strong top-down control of bacteria. Via bacterial grazing, these bacterivores liberate nutrients, which in turn, stimulate plant growth (Bonkowski, 2004). The quality and quantity of root-derived carbon sources vary temporally, between plant species and between individual plants that belong to the same plant species. This variation can be attributed, at least partly, to interactions between plants and other organisms. Foliar herbivory, but also interactions between roots and soil organisms such as root herbivores or mycorrhizal fungi (Jones et al., 2004; Bais et al., 2006), often causes an increase in the rate of carbon and nitrogen exudation from roots which then leads to enhanced microbial activity in the rhizosphere (Holland et al., 1996; Bardgett and Wardle, 2010). Hence, bacterial growth and activity will depend on the direct and indirect interactions of the plant with other (soil) organisms. Apart from consumption, movement of larger soil fauna also affects the dispersal of soil microorganisms such as bacteria. Thus, plant roots, bacteria, and other microbes interact in complex food webs and in order to understand the interactions between plants and bacteria it is important to consider them in a multitrophic context.

\section{PGPR AND PLANT DEFENSE}

Rhizobacteria with growth-promoting capacity occur in a number of bacterial phyla (Actinobacteria, Bacteroidetes, Cyanobacteria,
Firmicutes, Proteobacteria) with as best known members Pseudomonas spp. and Bacillus spp. (Compant et al., 2005). Studies on model organisms like Pseudomonas fluorescens have provided considerable understanding of the underlying molecular mechanisms of PGPR-induced plant defense. The type of defense triggered by microorganisms differs among pathogenic and non-pathogenic microbes (van Loon, 2007; Pieterse et al., 2012). Biotrophic pathogens generally induce systemic acquired resistance (SAR). SAR is dependent on salicylic acid (SA) signaling and results in enhanced expression of pathogenesis-related (PR) proteins (Durrant and Dong, 2004). By contrast, PGPR trigger ISR. ISR is generally independent of the SA signaling pathway and is not associated with major alterations in the expression of defense-related genes, but with priming of defenses (Verhagen et al., 2004). PGPRprimed plants do not have elevated expression of defense genes. Instead, they show more rapid or stronger activation of defenses once they are attacked by pathogens and herbivores, a response that is often dependent on a functional JA pathway (van der Ent et al., 2009). ISR is a systemic response, expressed in both roots and shoots, that can affect a wide range of organisms, including above- and belowground pathogens, herbivores, and their natural enemies (Pineda et al., 2010, 2012), a spectrum that only partly overlaps with that of SAR (van Oosten et al., 2008).

The effect of PGPR on plant growth promotion and on plant defense against attackers depends on many factors, including the plant species or genotype, the pathogen species, and the abiotic conditions, such as nutrient availability. In some cases variation in these factors can even lead to opposite effects of PGPR on plant traits. For instance, $P$. fluorescens addition stimulated nitrogen mineralization in one crop species and decreased it in another (Brimecombe et al., 1999). Similar variation in the effects of PGPR among plant species has been observed for their effects on plant defense against pathogens and herbivores. For instance, Tétard-Jones et al. (2007) showed that supplementing the rhizobacterial community with a Pseudomonas aeruginosa strain influenced the fitness of the cereal aphid (Sitobion avenae) on barley (Hordeum vulgare) either positively or negatively (increased or decreased population size) depending on plant and aphid genotype. In a later study (Tétard-Jones et al., 2012) they identified genomic regions (QTLs) underlying the differential plant-mediated responses to the rhizobacterium. This linking of differential responses to genomic regions is exceptional; often studies can only indicate that factors such as genotype may be relevant for the effectiveness of PGPR-triggered plant defense responses, without further mechanistic explanation. Many studies focusing on PGPR and induced defense have been carried out under relatively sterile conditions in laboratories or greenhouses. Studies on induced defense of $P$. fluorescens under field conditions are relatively rare. In this review we do include references to biocontrol studies but want to stress that biocontrol can be the result of many mechanisms of which ISR is only one. Studies testing whether effects of particular PGPR strains on plant defense observed under sterile greenhouse conditions can be observed in the field as well have yielded mixed results (e.g., Guo et al., 2004; Akila et al., 2011). When differences are observed, these could be due to the several biotic and abiotic factors which differ between greenhouse and the field. When 
spatial variation in the disease suppressive effects of PGPR are observed in field trials on multiple locations, abiotic factors such as fertility, temperature, and moisture are usually discussed as explanation for the variable results (Guo etal., 2004; Ji et al., 2006; Maeder et al., 2011). Remarkably, surprisingly little attention has been paid so far to the role of biotic factors such as local plant mutualists, predators, decomposers, other pathogens, or herbivores which might interfere with the PGPR effects on plant defense.

\section{Pseudomonas COMBINED WITH OTHER Pseudomonas STRAINS OR WITH OTHER PLANT MUTUALISTS}

Most plant species can have myriad mutualistic interactions, which provide benefits such as increasing nutrients, producing hormones, increasing tolerance to abiotic stresses (water, temperature, heavy metals), or biotic stresses (pests and pathogens). These benefits can be provided by both bacteria and fungi; depending on the mutualist species, the association can be on the root or leaf surface or inside the plants (endophytes). P. fluorescens is mostly known as a root colonizer. Many studies have examined the effects of adding several mutualistic organisms simultaneously to soils on plant defense (e.g., Jaderlund et al., 2008; Saravanakumar et al., 2009; Senthilraja et al., 2010). A general conclusion that can be drawn from these studies is that multiple microbial introductions typically are more effective than single introductions for biocontrol (Whipps, 2001).The combinations of species that have been added range from multiple Pseudomonas isolates (Saravanakumar et al., 2009; Seenivasan et al., 2012) to adding other mutualistic bacteria (Domenech et al., 2006) or mutualistic fungi (Jaderlund et al., 2008). The addition of multiple agents enhances the chance that at least one is well adapted to the local environment where the organisms are introduced. Disease suppression by the plant can also be improved when the introduced mutualists differ in their effects on induced defense responses (Domenech et al., 2006). Moreover, interactions between mutualists may lead to different gene expression and secondary metabolite production in the bacterium and this can result in synergistic effects of mutualists on the plant (Combes-Meynet et al., 2011; Garbeva etal., 2011). The studies by Garbeva etal. (2011) and Combes-Meynet et al. (2011) illustrate both the potential of bacteria species interactions to alter gene expression in $P$. fluorescens, and the potential effects that such changes in gene expression can have on the interactions with the plant. Even without altered gene expression in the bacteria, the plant may respond synergistically to the microbial-associated molecular patterns (MAMPs) of multiple plant mutualists (Desaki etal., 2012). MAMPs are molecules from pathogenic and mutualistic microbes which trigger plant immune response (van Wees et al., 2008). PGPR may vary their phenotype in order to avoid stimulation of the plants' immune system (Zamioudis and Pieterse, 2012). It is unknown how effective such phase variation is when other PGPR are also colonizing the plant, each species with their specific MAMPs, but triggering pathways that at some point converge (van Wees et al., 2008; Zamioudis and Pieterse, 2012). Currently not enough is known about the MAMPs of $P$. fluorescens and other mutualists to speculate about synergistic effects between more different MAMPs.

\section{Pseudomonas COMBINED WITH OTHER P. fluorescens STRAINS}

A number of studies have applied multiple strains of $P$. fluorescens to achieve better biocontrol of plant pests and pathogens, with the aim to find combinations of strains with complementary effects on plant defense. A recent study by Loper et al. (2012) on the genomes of 10 P. fluorescens strains shows that these strains vary considerable in their defense traits. This offers ample room for selection of complementary strains and different lifestyles. Agusti et al. (2011) selected two P. fluorescens strains which differed in secondary metabolite production and found that dual inoculations lead to better control of Phytophthora cactorum in strawberry, as well as to a reduction of the within-experiment variability, compared to single introductions. Several studies have reported that a combination of introductions of P. fluorescens isolates Pf1, TDK1, and PY15 is very effective in controlling pests and diseases. Introduction of the combination of the three $P$. fluorescens isolates, for example, is very effective in reducing populations of the root-feeding nematode Meloidogyne graminicola (Seenivasan et al., 2012) as well as in controlling sheath rot Sarocladium oryzae in rice (Saravanakumar et al., 2009). The explanation for the effectiveness of this particular combination is that these three isolates do not compete for space and together colonize the root surface more effectively than single isolates. This is important for the direct nematicidal effects of the isolates. However, plants inoculated with P. fluorescens mixtures also had higher activities of peroxidase and chitinase enzymes than single inoculations (Saravanakumar et al., 2009; Seenivasan et al., 2012), suggesting that higher activation of defense-related enzymes may play a role in addition to a more efficient occupation of the root surface.

\section{Pseudomonas COMBINED WITH OTHER SPECIES OF PGPR}

The most commonly investigated combination of $P$. fluorescens and other PGPR is with Bacillus spp., but also combined introductions with Burkholderia spp., Rhizobium spp., and Serratia spp. are frequently studied. For Bacillus spp., as far as we are aware, no antagonistic effects on control of bacteria, fungi, and viruses have been reported. García-Gutiérrez et al. (2012) tested suppression of both fungal and bacterial pathogens by $P$. fluorescens in combination with Bacillus; combinations were equally effective as single introductions of $P$. fluorescens. The improved control of Fusarium disease by a combination of $P$. fluorescens and Bacillus was associated with the induction of the defenserelated enzymes peroxidase and polyphenol oxidase (Akila et al., 2011; Sundaramoorthy et al., 2012). Most studies on the effects of combined introductions of Pseudomonas and other PGPR have reported effects on improved biological control. CombesMeynet etal. (2011) hypothesized that during evolution PGPR have developed mechanisms to affect and respond to each other and that it is likely that the secondary metabolites from $P$. fluorescens will affect other PGPR. The authors tested the effect of 2,4-diacetylphloroglucinol (2,4-DAPG), a secondary metabolite from P. fluorescens, on Azospirillum gene expression and found that genes involved in several traits related to root colonization and growth promotion were upregulated. Co-inoculation of $P$. fluorescens and Azospirillum stimulated root growth in spring wheat (Combes-Meynet et al., 2011). Garbeva et al. (2011) studied changes in gene expression in $P$. fluorescens when exposed to three 
other rhizobacteria: Bacillus sp., Brevundimonas sp., or Pedobacter sp. Interestingly, $P$. fluorescens had specific responses to the different competitors; two species increased antimicrobial metabolite production by $P$. fluorescens, but Bacillus did not (Garbeva et al., 2011). There are also studies where inoculation with $P$. fluorescens alone was more effective than inoculations in which Pseudomonas was combined with other PGPR (Anwar-ul-Haq et al., 2011; Stockwell etal., 2011). P. fluorescens A506 proved incompatible with two other biological control agents Pantoea vagans and Pantoea agglomerans since proteases from $P$. fluorescens A506 degrade the antibiotics from the Pantoea spp. that play an important role in the control fire blight in pear (Stockwell et al., 2011).

\section{Pseudomonas COMBINED WITH FUNGI}

Fungi are introduced together with $P$. fluorescens with three main aims: improved nutrition or plant growth (mycorrhizal fungi), improved disease control (e.g., Trichoderma spp.) or improved insect pest control (Beauveria spp.). So far, there are only a few papers that have examined the effectiveness of combined introductions of Pseudomonas with the entomopathogenic fungus Beauveria. Entomopathogenic fungi can be found as plant endophyte and may have plant growth-promoting properties (Vega et al., 2009). The majority of papers report increased control of pests or diseases when the entomopathogenic fungus Beauveria is applied in combination with $P$. fluorescens. Senthilraja et al. (2010) used combinations of $P$. fluorescens and Beauveria bassiana and found the three-strain combination of two $P$. fluorescens strains with one Beauveria bassiana to be more effective than single or two-strain inoculations for controlling both a leafminer and collar rot. The explanation is that $P$. fluorescens affects plant metabolism, and this, in turn, makes the insects more vulnerable to Beauveria. Similarly, Karthiba et al. (2010) combined P. fluorescens with Beauveria bassiana, and found simultaneous control of pests and pathogens on rice.

Pseudomonas fluorescens is known to control pathogens including fungi, and thus we may anticipate that combined effects of $P$. fluorescens and mutualistic fungi on plant resistance will be less than additive because mutualistic fungi will suffer from $P$. fluorescens. On the other hand, Pseudomonas fluorescens is identified as one of the mycorrhiza helper bacteria for both ecto- and arbuscular mycorrhiza (Frey-Klett et al., 2007). Mycorrhiza helper bacteria are bacteria associated with mycorrhiza that promote the symbiosis between fungus and plant by stimulating fungal growth or protecting the fungus against other fungal competitors. There are many examples where $P$. fluorescens combined with mutualistic fungi was more successful than single inoculations of either bacteria or fungi (Tayal et al., 2011; Walker et al., 2012), and antagonistic interactions have rarely been reported (but see Sukhada et al., 2011). Inoculation of the mycorrhizal fungus Glomus intraradices has a positive effect on $P$. fluorescens survival on maize; it is unclear whether this is a plant-mediated or direct effect (Walker et al., 2012). Sukhada et al. (2011) found both under controlled conditions and in the field that the tripartite inoculation of $P$. fluorescens with the arbuscular mycorrhizal fungi G. mosseae and with T. harzianum was not as good in reducing Phytophthora disease incidence as the dual inoculations. It is unknown whether the predominantly positive results of mutualistic fungi with $P$. fluorescens indicates that natural selection has favored traits that result in interactions between mutualistic fungi and $P$. fluorescens that are neutral or positive for the plant or whether this reflects the research bias towards studies using candidates with good prospects for positive interactions in their effects on biocontrol. Another major group of mutualistic fungi are the Class I endophytes Neotyphodium spp. and Acremonium spp. but little is known about their effects on belowground processes, except for a stimulation of root exudation (Omacini et al., 2012). Recently, Wicklow and Poling (2009) showed that there are negative effects of antibiotics from Acremonium zeae on P. fluorescens, but apart from that, we are not aware of any study examining the effects of plant - endophyte P. fluorescens interactions on plant defense.

\section{INTERACTIONS BETWEEN Pseudomonas AND BACTERIVORES AND DECOMPOSERS}

Pseudomonas fluorescens may also interact with two other groups of rhizosphere organisms that have less close relations with the plant: organisms which feed on bacteria (bacterivores) and organisms which break down organic material (decomposers).

\section{Pseudomonas fluorescens AND BACTERIVORES}

Pseudomonas fluorescens are grazed by predatory bacteria, protozoa, and bacterivorous nematodes (Elsherif and Grossmann, 1996). For bacterivores there is a clear potential direct effect on P. fluorescens abundance via grazing. However, whether grazing will affect plant defense is dependent on the selectivity of grazing and whether induction of plant defense is density-dependent. A threshold density of $P$. fluorescens is known for effective suppression of take-all decline (Raaijmakers and Weller, 1998) but it is unclear if the same applies to other pests and diseases. Selective grazing can change bacterial competition (Pedersen et al., 2009) and bacterivores avoiding P. fluorescens due to the secondary metabolite production by $P$. fluorescens can improve the competitive advantage of $P$. fluorescens over other bacteria (Jousset et al., 2008; Jousset, 2012). Pseudomonas can produce hydrogen cyanide and this repels bacterivorous nematodes. Also 2,4-DAPG, an antibiotic compound produced by $P$. fluorescens, acts as nematicide (Neidig et al., 2011). However, even when P. fluorescens is grazed upon by predators, a reduction in ISR response is not selfevident, because the reduction in abundance by predation may be accompanied by other changes in the PGPR that enhance ISR. For instance, grazing by amoebae was found to upregulate 2,4-DAPG synthesis in P. fluorescens (Jousset and Bonkowski, 2010). This compound is also known to be directly involved in ISR in plants (Weller et al., 2012). Bacterivorous nematodes can also stimulate PGPR effects on plant growth (Jiang et al., 2012). Addition of bacterivorous nematodes together with Burkholderia or Pseudomonas to plants growing in natural soil increased microbial biomass (Jiang et al., 2012), indicating a stimulation of bacterial abundance by grazing. Both nematode addition and Burkholderia addition increased the number of root tips, but their combined effect was significantly higher than their single effects (Jiang et al., 2012). There is an urgent need for experiments, that include bacterivores, P. fluorescens, plants, and pathogens in which the expression of plant defense or defense genes are measured. We are not aware of any of such studies. 


\section{Pseudomonas fluorescens AND DECOMPOSERS}

For decomposers more and more evidence is accumulating that they can affect induced defense responses of plants. For instance, Collembola induce auxin-responsive genes and defense genes in shoots of Arabidopsis (Endlweber et al., 2011), although in this case Collembola may act as herbivores instead of decomposers. Earthworms reduced the damage by plant parasitic nematodes in rice, without directly affecting nematode abundance (Blouin et al., 2005). The exact mechanism is unknown, but earthworms did modulate expression of three stress-related genes and they also improved the photosynthetic capacity of the plant (Blouin et al., 2005). The presence of earthworms in the soil can also cause an increase or decrease in defensive glucosinolates in Brassicaceous plants (Wurst et al., 2006; Lohmann et al., 2009; González Megías and Müller, 2010). These results clearly show that decomposers can affect plant defense and therefore, decomposers may interact with $P$. fluorescens-mediated ISR. Indirect effects of decomposers on P. fluorescens-plant outcomes may occur via changes in nutrient availability and substrate quality, and several studies have indicated that soil nutritional conditions are crucial for ISR (e.g., Hoitink and Boehm, 1999). It is also possible that decomposers affect plant growth and root exudation, and that this in turn affects P. fluorescens abundance and ultimately plant defense. However, we are not aware of any study describing effects of decomposers on P. fluorescens-plant interactions. For other PGPR it has been shown that earthworm casts increased PGPR abundances (Wu et al., 2012). Jana et al. (2010) investigated the effects of earthworms on Arabidopsis thaliana in nutrient poor and rich soil. Since earthworms affected several plant parameters independent of soil nutrient conditions, the authors suggested that earthworms stimulate nutrient mineralization but also stimulate phytohormone-producing bacteria (Jana et al., 2010). In another study, earthworms increased the abundance of fluorescent pseudomonads in the rhizosphere of three plant species (Elmer, 2009), and therefore these results suggest that this may be a general phenomenon. The mechanism of stimulation is unknown, but Troxler et al. (2012) observed that earthworms provide survival hotspots for $P$. fluorescens in soil.

\section{SYNTHESIS, APPLICATION, AND OUTLOOK}

The effect of other soil dwelling organisms on the impact of $P$. fluorescence on plant defense responses will depend on whether there is a threshold density and whether the effects are (linear or non-linear) density-dependent. If other PGPR organisms target the same ISR mechanism then one could easily imagine additive interactions if there is a linear relationship between density at introduction and the effect on the plant. If the relation between density and plant response is non-linear there is room for synergistic reactions. There are several mechanisms by which the presence of other organisms can influence interactions between P. fluorescens, host plants, and herbivores or pathogens (Figure 1). The other species can act directly via affecting abundance or effectiveness of $P$. fluorescens and indirectly via plant-mediated effects. The direct effects can be separated into quantitative and qualitative effects: the quantitative effects are those that determine the number of $P$. fluorescens cells in the rhizosphere. The qualitative effects determine the effectiveness of $P$. fluorescens in triggering plant defense, e.g., by changing 2,4-DAPG production. The number of $P$. fluorescens cells can be decreased due to predation by bacterivores, such as predatory bacteria, nematodes, and protozoa (Figure 1; Pedersen et al., 2009). Pseudomonas fluorescens is a suitable food source for bacterivores (Elsherif and Grossmann, 1996), but $P$. fluorescens can produce defense compounds to avoid predation. The overall effect of grazing on $P$. fluorescens population dynamics will depend on the defense levels of $P$. fluorescens, the availability of alternative food sources and the selectivity of the grazers. We do not foresee an immediate application of combining $P$. fluorescens inoculation with bacterivores to increase root colonization.

Competition for nutrients or space with other PGPR or rhizobacteria is another factor that will negatively affect $P$. fluorescens numbers (Figure 1; Prieto etal., 2011). Other PGPR could also produce secondary metabolites which inhibit $P$. fluorescens (Figure 1; Gu, 2009). Many efforts have been made to isolate and screen $P$. fluorescens strains and to select successful combinations of multiple P. fluorescens strains or other PGPR. Recent developments have now enabled screenings of $P$. fluorescens genomes for defense traits and this could help with selection of compatible and potential synergistic strains. Synergistic interactions between P. fluorescens and other plant mutualists are much more common than antagonistic interactions, but this may be due to a bias in experimental studies to use species with prospects of positive interactive effects on biocontrol. Only the most promising strains are selected and these are first tested for compatibility, i.e., absence of in vitro inhibition (e.g., Sundaramoorthy et al., 2012) or competition during root colonization (Prieto et al., 2011). This approach probably provides a biased view of the effects of interactions between mutualist species on plant defense. For inoculation approaches this screening approach is very efficient, but for understanding interactions between introduced P. fluorescens with the resident biocontrol agents knowledge of a broader range of species interactions is necessary. Application of single $P$. fluorescens requires knowledge on potential interactions with resident $P$. fluorescens and other organisms. At least 22 genotypes of 2,4-DAPG-producing $P$. fluorescens have been detected thus far; multiple isolates are found together in soils (Weller et al., 2007) and thus interactions between resident and inoculated $P$. fluorescens are likely to occur. Also other PGPR are widespread and they can interact with introduced $P$. fluorescens. Those groups that negatively affect $P$. fluorescens abundance (bacterivores and other PGPR) may also trigger secondary metabolite production in $P$. fluorescens (qualitative effect). Those secondary metabolites such as 2,4-DAPG serve as defense compounds against predators but are also involved in ISR in plants (Weller et al., 2012). Upregulation of such inducing compounds probably lowers the threshold density necessary to induce ISR in plants. Garbeva et al. (2011) showed how some PGPR increased secondary metabolites production in $P$. fluorescens while other PGPR did not change secondary metabolite production. This variation in interactions allows for selection of compatible PGPR combinations, but prediction of field effects due to interactions with resident species will remain problematic. For most field situations there is no knowledge of the resident $P$. fluorescens and other PGPR. The fast developments in molecular techniques continuously improve 


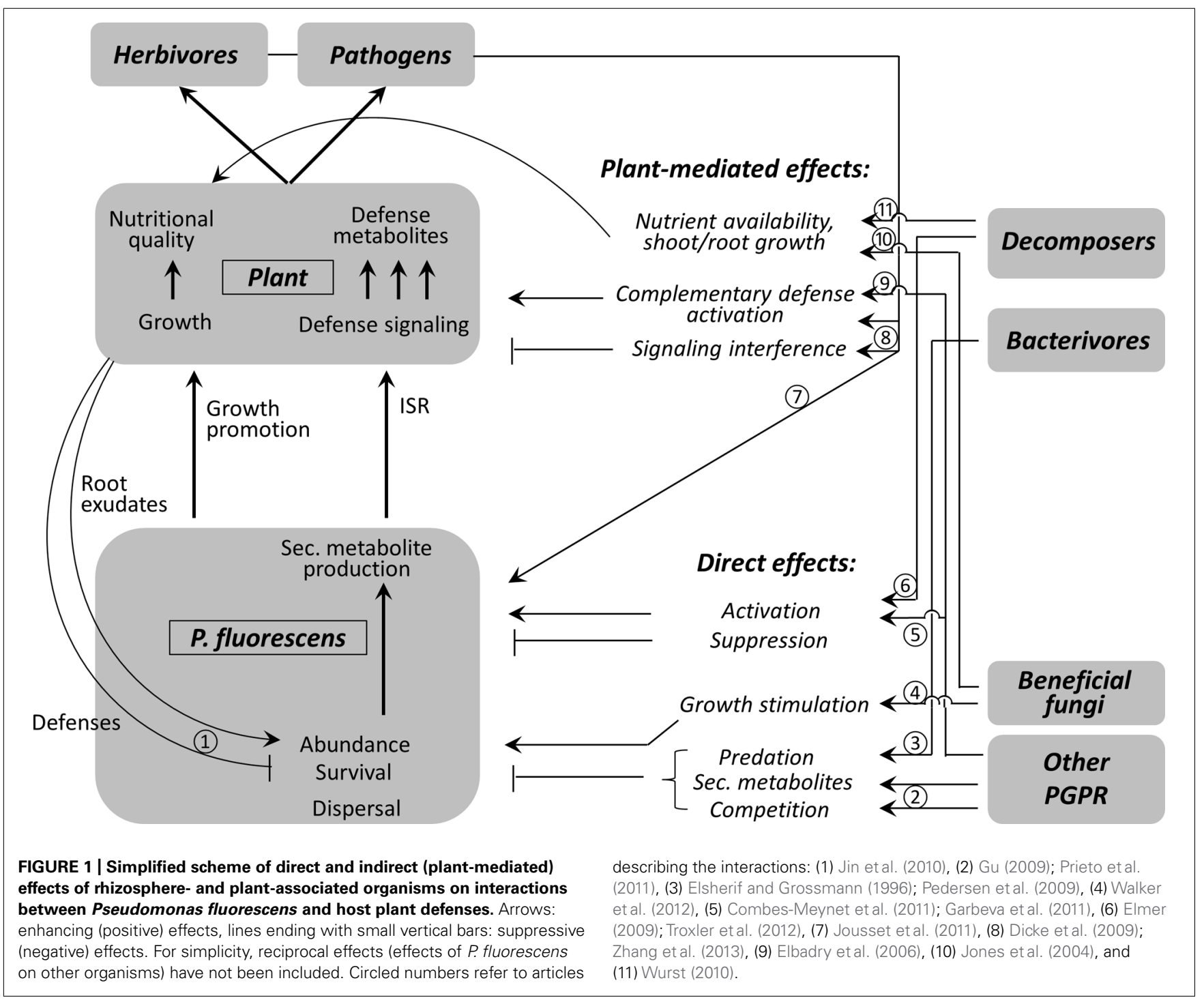

the resolution at which microbial community composition can be assessed. Even when composition of the local bacterial community is known, this knowledge would be of little use when for most species nothing is known about their potential interaction with introduced $P$. fluorescens. Metagenomics and transcriptomics will offer insight in activity and function of the microbiome, especially the recruitment and activation of beneficials (Berendsen et al., 2012).

Both decomposers (Elmer, 2009; Troxler et al., 2012) and mycorrhizal fungi (Walker et al., 2012) can have positive effects on the number of $P$. fluorescens cells in the rhizosphere. However, there is only a single report for stimulation of $P$. fluorescens survival by mycorrhizal fungi and hence the generality of this phenomenon remains unclear. The exact mechanism of $P$. fluorescens stimulation by decomposers and mycorrhiza is still unknown. However, regardless of the mechanism, the positive effect of decomposers and possibly mycorrhizal fungi on $P$. fluorescens abundance and dispersal could be exploited by adapting management practices to, e.g., stimulate earthworms by organic amendments. Tillage and fertilization could be adapted to favor arbuscular mycorrhizal fungi. Apart from promoting PGPR, it is clear that there are many other reasons why decomposers or arbuscular mycorrhizal fungi are stimulated in agricultural soils, although such management practises are often not yet adopted in intensive agricultural systems.

Indirect effects via plant feedback comprise a multitude of interactions. Decomposers and beneficial fungi may increase nutrient availability and increase shoot and root growth (Laakso and Setälä, 1999; Jones et al., 2004). The increased growth may change plant defense and root exudation patterns and this, in turn, can affect $P$. fluorescens populations (Jin et al., 2010). With the recently increased awareness of the indirect effects of decomposers on plant defense (e.g., Wurst, 2010), the interaction between P. fluorescens, plants, and plant-decomposer is a research area waiting to be explored.

Although there certainly is interest in the control of multiple pests or pathogens simultaneously (Karthiba et al., 2010; Senthilraja et al., 2010), most experiments thus far have tested 
the effect of $P$. fluorescens on control of pathogens separately. Experiments, where the effect of one pathogen on the interaction with another pathogen and $P$. fluorescens has been studied, are scarce. Pathogens, mutualists, and pests with intimate relationships with the plant such as aphids or cyst nematodes might be able to synergize or antagonize the ISR-triggered responses through interference with defense signaling or activation/repression of downstream defenses. The pathogen Pythium ultimum can change 2,4-DAPG production by P. fluorescens (Jousset et al., 2011), but it is currently unknown how that would affect a second attacker. For insects, interspecific asymmetrical competition is frequently found (Kaplan and Denno, 2007). Therefore, control of one insect pest could result in an increase in abundance of another. Some plant-nematode combinations are sensitive to $P$. fluorescens, but not all (Timper et al., 2009). Thus, similar to insects, controlling one nematode pest might affect the abundance of other nematode species for example by changing competition for root space (Brinkman et al., 2004). A single plant which is attacked by multiple herbivores, pathogens or herbivores and pathogens would have to deal with a number of possible conflicting signals. A second attacker could activate or repress downstream defenses induced by a previous attacker (Dicke et al., 2009; Zhang et al., 2013). In this

\section{REFERENCES}

Agusti, L., Bonaterra, A., Moragrega, C., Camps, J., and Montesinos, E. (2011). Biocontrol of root rot of strawberry caused by Phytophthora cactorum with a combination of two Pseudomonas fluorescens strains. J. Plant Pathol. 93, 363-372.

Akila, R., Rajendran, L., Harish, S., Saveetha, K., Raguchander, T., and Samiyappan, R. (2011). Combined application of botanical formulations and biocontrol agents for the management of Fusarium oxysporum $\mathrm{f}$. sp. cubense (Foc) causing Fusarium wilt in banana. Biol. Control 57, 175-183.

Anwar-ul-Haq, M., Anwar, S. A., Shahid, M., Javed, N., Khan, S. A., and Mehamood, K. (2011). Management of root knot nematode Meloidogyne incognita by plant growth-promoting rhizobacteria on tomato. Pak. J. Zool. 43, 1027-1031.

Bais, H. P., Loyola-Vargas, V. M., Flores, H. E., and Vivanco, J. M. (2001). Root-specific metabolism: the biology and biochemistry of underground organs. In Vitro Cell. Dev. Plant 37, 730-741.

Bais, H. P., Weir, T. L., Perry, L. G., Gilroy, S., and Vivanco, J. M. (2006). The role of root exudates in rhizosphere interactions with plants and other organisms. Annu. Rev. Plant Biol. 233-266.

Bardgett, R. D. (2005). The Biology of Soil: a Community and Ecosystem Approach. Oxford: Oxford University Press.

Bardgett, R. D., and Wardle, D. A. (2010). Above-Belowground Linkages:
Biotic Interactions, Ecosystem Processes, and Global Change. Oxford: Oxford University Press.

Berendsen, R. L., Pieterse, C. M. J., and Bakker, P. A. H. M. (2012). The rhizosphere microbiome and plant health. Trends Plant Sci. 17, 478-486.

Blouin, M., Zuily-Fodil, Y., Pham-Thi, A. T., Laffray, D., Reversat, G., Pando, A., et al. (2005). Belowground organism activities affect plant aboveground phenotype, inducing plant tolerance to parasites. Ecol. Lett. 8, 202-208.

Bonkowski, M. (2004). Protozoa and plant growth: the microbial loop in soil revisited. New Phytol. 162, 617-631.

Brimecombe, M. J., De Leij, F., and Lynch, J. M. (1999). Effect of introduced Pseudomonas fluorescens strains on the uptake of nitrogen by wheat from N-15-enriched organic residues. World J. Microbiol. Biotechnol. 15, 417-423.

Brinkman, E. P., van Veen, J. A., and van der Putten, W. H. (2004). Endoparasitic nematodes reduce multiplication of ectoparasitic nematodes, but do not prevent growth reduction of Ammophila arenaria (L.) Link (marram grass). Appl. Soil Ecol. 27, 65-75.

Combes-Meynet, E., Pothier, J. F., Moenne-Loccoz, Y., and PrigentCombaret, C. (2011). The Pseudomonas secondary metabolite 2,4-diacetylphloroglucinol is a signal inducing rhizoplane expression of Azospirillum genes involved in plant-growth promotion. Mol. Plant Microbe Interact. 24, 271-284.

respect the order by which a plant is attacked is crucial for plant defense induction. Priority effects are receiving increasingly more attention recently, also in the context of plant-soil interactions, but mostly from the plant perspective. However, there is very little empirical work on the interactions between $P$. fluorescens, a host plant, and multiple attackers. In fact, empirical studies that examine how interactions between herbivores, pathogens, mutualists, decomposers, or bacterivores affect plant- $P$. fluorescens interactions in a full-factorial design are non-existing and can only be addressed by individual-based models of plant-based multitrophic species interactions, such as in Meyer et al. (2009). We conclude that other rhizosphere inhabitants can greatly influence $P$. fluorescens and its interactions with the plant. However, there is still a dearth of information about the effects of other species on interactions between $P$. fluorescens and plant defense. Insight into these interactions will contribute to improved performance of biocontrol agents in the field.

\section{ACKNOWLEDGMENTS}

We thank Prof. Wim van der Putten for critically reading earlier drafts of the manuscript. This is publication 5434 of NIOO-KNAW.

Compant, S., Duffy, B., Nowak, J., Clement, C., and Barka, E. A. (2005). Use of plant-growth promoting bacteria for biocontrol of plant diseases: principles, mechanisms, and future prospects. Appl. Environ. Microbiol. 71, 4951-4959.

Desaki, Y., Otomo, I., Kobayashi, D., Jikumaru, Y., Kamiya, Y., Venkatesh, B., et al. (2012). Positive crosstalk of MAMP signaling pathways in rice cells. PLoS ONE 7:e51953. doi: 10.1371/journal.pone.0051953

Dicke, M., and Baldwin, I. T. (2010). The evolutionary context for herbivore-induced plant volatiles: beyond the 'cry for help'. Trends Plant Sci. 15, 167-175.

Dicke, M., van Loon, J. J. A., and Soler, R. (2009). Chemical complexity of volatiles from plants induced by multiple attack. Nat. Chem. Biol. 5, 317-324.

Domenech, J., Reddy, M. S., Kloepper, J. W., Ramos, B., and GutierrezManero, J. (2006). Combined application of the biological product LS213 with Bacillus, Pseudomonas or Chryseobacterium for growth promotion and biological control of soilborne diseases in pepper and tomato. Biocontrol 51, 245-258.

Durrant, W. E., and Dong, X. (2004). Systemic acquired resistance. Annu. Rev. Phytopathol. 42, 185-209.

Elbadry, M., Tahaa, R. M., Eldougdoug, K. A., and Gamal-Eldin, H. (2006). Induction of systemic resistance in faba bean (Vicia faba L.) to bean yellow mosaic potyvirus (BYMV) via seed bacterization with plant growth promoting rhizobacteria. J. Plant Dis. Prot. 113, 247-251.

Elmer, W. H. (2009). Influence of earthworm activity on soil microbes and soilborne diseases of vegetables. Plant Dis. 93, 175-179.

Elsherif, M., and Grossmann, F. (1996). Role of biotic factors in the control of soil-borne fungi by fluorescent pseudomonads. Microbiol. Res. 151, 351-357.

Endlweber, K., Krome, K., Welzl, G., Schaffner, A. R., and Scheu, S. (2011). Decomposer animals induce differential expression of defence and auxin-responsive genes in plants. Soil Biol. Biochem. 43, 1130-1138.

Frey-Klett, P., Garbaye, J., and Tarkka, M. (2007). The mycorrhiza helper bacteria revisited. New Phytol. 176, 22-36.

Garbeva, P., Silby, M. W., Raaijmakers, J. M., Levy, S. B., and de Boer, W. (2011). Transcriptional and antagonistic responses of Pseudomonas fluorescens Pf0-1 to phylogenetically different bacterial competitors. ISME J. 5, 973-985.

García-Gutiérrez, L., Romero, D., Zeriouh, H., Cazorla, F. M., Torés, J. A., DeVicente, A., etal. (2012). Isolation and selection of plant growthpromoting rhizobacteria as inducers of systemic resistance in melon. Plant Soil 358, 201-212.

González Megías, A., and Müller, C. (2010). Root herbivores and detritivores shape above-ground multitrophic assemblage through plant-mediated effects. J. Anim. Ecol. 79, 923-931. 
Gu, W. (2009). Bioactive metabolies from Alternaria brassicicola ML-P08, an endophytic fungus residing in Malus halliana. World J. Microbiol. Biotechnol. 25, 1677-1683.

Guo, J. H., Qi, H. Y., Guo, Y. H., Ge, H. L., Gong, L. Y., Zhang, L. X., et al. (2004). Biocontrol of tomato wilt by plant growth-promoting rhizobacteria. Biol. Control 29, 66-72.

Hoitink, H. A. J., and Boehm, M. J. (1999). Biocontrol within the context of soil microbial communities: a substrate-dependent phenomenon. Annu. Rev. Phytopathol. 37, 427-446.

Holland, J. N., Cheng, W. X., and Crossley, D. A. (1996). Herbivore-induced changes in plant carbon allocation: assessment of below-ground $\mathrm{C}$ fluxes using carbon-14. Oecologia 107, 87-94.

Jaderlund, L., Arthurson, V., Granhall, U., and Jansson, J. K. (2008). Specific interactions between arbuscular mycorrhizal fungi and plant growthpromoting bacteria: as revealed by different combinations. FEMS Microbiol. Lett. 287, 174-180.

Jana, U., Barot, S., Blouin, M., Lavelle, P., Laffray, D., and Repellin, A. (2010). Earthworms influence the production of above- and belowground biomass and the expression of genes involved in cell proliferation and stress responses in Arabidopsis thaliana. Soil Biol. Biochem. 42, 244-252.

Ji, P., Campbell, H. L., Kloepper, J. W., Jones, J. B., Suslow, T. V., and Wilson, M. (2006). Integrated biological control of bacterial speck and spot of tomato under field conditions using foliar biological control agents and plant growth-promoting rhizobacteria. Biol. Control 36, 358-367.

Jin, C. W., Li, G. X., Yu, X. H., and Zheng, S. J. (2010). Plant Fe status affects the composition of siderophore-secreting microbes in the rhizosphere. Ann. Bot. 105, 835-841.

Jiang, Y., Wu, Y., Xu, W. S. Cheng, Y. H., Chen, J. D., Xu, L., et al. (2012). IAA-producing bacteria and bacterial-feeding nematodes promote Arabidopsis thaliana root growth in natural soil. Eur. J. Soil Biol. $52,20-26$.

Jones, D. L., Hodge, A., and Kuzyakov, Y. (2004). Plant and mycorrhizal regulation of rhizodeposition. New Phytol. $163,459-480$.

Jousset, A. (2012). Ecological and evolutive implications of bacterial defences against predators. Environ. Microbiol. 14, 1830-1843.

Jousset, A., and Bonkowski, M. (2010). The model predator Acanthamoeba castellanii induces the production of 2,4-DAPG by the biocontrol strain Pseudomonas fluorescens Q2-87. Soil Biol. Biochem. 42, 1647-1649.

Jousset, A., Rochat, L., Lanoue, A., Bonkowski, M., Keel, C., and Scheu, S. (2011). Plants respond to pathogen infection by enhancing the antifungal gene expression of root-associated bacteria. Mol. Plant Microbe Interact. 24, 352-358.

Jousset, A., Scheu, S., and Bonkowski, M. (2008). Secondary metabolite production facilitates establishment of rhizobacteria by reducing both protozoan predation and the competitive effects of indigenous bacteria. Funct. Ecol. 22, 714-719.

Kaplan, I., and Denno, R. F. (2007) Interspecific interactions in phytophagous insects revisited: a quantitative assessment of competition theory. Ecol. Lett. 10, 977-994.

Karthiba, L., Saveetha, K., Suresh, S., Raguchander, T., Saravanakumar, D., and Samiyappan, R. (2010). PGPR and entomopathogenic fungus bioformulation for the synchronous management of leaffolder pest and sheath blight disease of rice. Pest Manag. Sci. 66, 555-564.

Laakso, J., and Setälä, H. (1999). Sensitivity of primary production to changes in the architecture of belowground food webs. Oikos 87, 57-64.

Lohmann, M., Scheu, S., and Müller, C. (2009). Decomposers and root feeders interactively affect plant defence in Sinapis alba. Oecologia 160 289-298.

Loper, J. E., Hassan, K. A., Mavrodi, D. V., Davis, E. W., Lim, C. K., Shaffer, B. T., et al. (2012). Comparative genomics of plantassociated Pseudomonas spp.: insights into diversity and inheritance of traits involved in multitrophic interactions. PLoS Genet. 8:e1002784. doi 10.1371/journal.pgen.1002784

Maeder, P., Kaiser, F., Adholeya, A., Singh, R., Uppal, H. S., Sharma A. K., etal. (2011). Inoculation of root microorganisms for sustainable wheat-rice and wheat-black gram rotations in India. Soil Biol. Biochem. 43, 609-619.

Meyer, K. M., Vos, M., Mooij, W. M., Hol, W. H. G., Termorshuizen, A. J., Vet, L. E. M., et al. (2009). Quantifying the impact of above- and belowground higher trophic levels on plant and herbivore performance by modeling. Oikos 118, 981-990.

Neidig, N., Paul, R. J., Scheu, S., and Jousset, A. (2011). Secondary metabolites of Pseudomonas fluorescens CHA0 drive complex non-trophic interactions with bacterivorous nematodes. Microb. Ecol. 61, 853-859.

Omacini, M. Semmartin, M., Perez, L. I., and Gundel, P. E. (2012). Grass endophyte symbiosis: a neglected aboveground interaction with multiple belowground consequences. Appl. Soil Ecol. 61, 273-279.

Pedersen, A. L., Nybroe, O., Winding, A., Ekelund, F., and Bjornlund, L. (2009). Bacterial feeders, the nematode Caenorhabditis elegans and the flagellate Cercomonas longicauda, have different effects on outcome of competition among the Pseudomonas biocontrol strains CHA0 and DSS73. Microb. Ecol. 57, 501-509.

Pieterse, C. M. J., and Dicke, M. (2007). Plant interactions with microbes and insects: from molecular mechanisms to ecology. Trends Plant Sci. 12, 13601385.

Pieterse, C. M. J., van der Does, D., Zamioudis, C., Leon-Reyes, A., and van Wees, S. C. M. (2012). Hormonal modulation of plant immunity. Annu. Rev. Cell Dev. Biol. 28, 489-521.

Pineda, A., Zheng, S. J., van Loon, J. J. A., and Dicke, M. (2012). Rhizobacteria modify plant-aphid interactions: a case of induced systemic susceptibility. Plant Biol. 14, 83-90.

Pineda, A., Zheng, S. J., van Loon, J. J. A., Pieterse, C. M. J., and Dicke, M. (2010). Helping plants to deal with insects: the role of beneficial soilborne microbes. Trends Plant Sci. 15 507-514.

Prieto, P., Schiliro, E., MaldonadoGonzalez, M. M., Valderrama, R., Barroso-Albarracin, J. B., and Mercado-Blanco, J. (2011). Root hairs play a key role in the endophytic colonization of olive roots by Pseudomonas spp. with biocontrol activity. Microb. Ecol. 62, 435-445.

Raaijmakers, J. M., and Weller, D. M. (1998). Natural plant protection by 2,4-diacetylphloroglucinol - producing Pseudomonas spp. in takeall decline soils. Mol. Plant Microbe Interact. 11, 144-152.

Saravanakumar, D., Lavanya, N., Muthumeena, K., Raguchander, T., and Samiyappan, R. (2009). Fluorescent pseudomonad mixtures mediate disease resistance in rice plants against sheath rot (Sarocladium oryzae) disease. Biocontrol 54, 273-286.

Seenivasan, N., David, P. M. M., Vivekanandan, P., and Samiyappan, R. (2012). Biological control of rice root-knot nematode, Meloidogyne graminicola through mixture of $\mathrm{Pseu}$ domonas fluorescens strains. Biocontrol Sci. Technol. 22, 611-632.
Senthilraja, G., Anand, T., Durairaj, C., Raguchander, T., and Samiyappan, R. (2010). Chitin-based bioformulation of Beauveria bassiana and Pseudomonas fluorescens for improved control of leafminer and collar rot in groundnut. Crop Prot. 29, 10031010.

Stockwell, V. O., Johnson, K. B., Sugar, D., and Loper, J. E. (2011). Mechanistically compatible mixtures of bacterial antagonists improve biological control of fire blight of pear. Phytopathology 101, 113-123.

Sukhada, M., Manjula, R., and Rawal, R. D. (2011). Evaluation of arbuscular mycorrhiza and other biocontrol agents against Phytophthora parasitica var. nicotianae infecting papaya (Carica papaya cv. Surya) and enumeration of pathogen population using immunotechniques. Biol. Control 58, 22-29.

Sundaramoorthy, S., Raguchander, T., Ragupathi, N., and Samiyappan, R. (2012). Combinatorial effect of endophytic and plant growthpromoting rhizobacteria against wilt disease of Capsicum annum L. caused by Fusarium solani. Biol. Control 60, 59-67.

Tayal, P., Kapoor, R., and Bhatnagar, A. K. (2011). Functional synergism among Glomus fasciculatum, Trichoderma viride and Pseudomonas fluorescens on Fusarium wilt in tomato. J. Plant Pathol. 93, 745-750.

Tétard-Jones, C., Kertesz, M. A., Gallois, P., and Preziosi, R. F. (2007). Genotype-by-genotype interactions modified by a third species in a plant-insect system. Am. Nat. 170, 492-499.

Tétard-Jones, C., Kertesz, M. A., and Preziosi, R. F. (2012). Identification of plant quantitative trait loci modulating a rhizobacteria-aphid indirect effect. PLoS ONE 7:e41524. doi: 10.1371/journal.pone.0041524

Timper, P., Kone, D., Yin, J. F., Ji, P. S., and Gardener, B. B. M. (2009). Evaluation of an antibioticproducing strain of Pseudomonas fluorescens for suppression of plantparasitic nematodes. J. Nematol. 41, 234-240.

Troxler, J., Svercel, M., Natsch, A., Zala, M., Keel, C., Moenne-Loccoz, Y., etal. (2012). Persistence of a biocontrol Pseudomonas inoculant as high populations of culturable and non-culturable cells in 200-cm-deep soil profiles. Soil Biol. Biochem. 44, 122-129.

van der Ent, S., van Wees, S. C. M., and Pieterse, C. M. J. (2009). Jasmonate signaling in plant interactions with resistance-inducing 
beneficial microbes. Phytochemistry 70, 1581-1588.

van Loon, L. C. (2007). Plant responses to plant growth-promoting rhizobacteria. Eur. J. Plant Pathol. 119, 243-254.

van Oosten, V. R., Bodenhausen, N., Reymond, P., van Pelt, J. A., van Loon, L. C., Dicke, M., et al. (2008). Differential effectiveness of microbially induced resistance against herbivorous insects in Arabidopsis. Mol. Plant Microbe Interact. 21, 919-930.

van Wees, S. C. M., van der Ent, S., and Pieterse, C. M. J. (2008). Plant immune responses triggered by beneficial microbes. Curr. Opin. Plant Biol. 11, 443-448.

Vega, F. E., Goettel, M. S., Blackwell, M., Chandler, D., Jackson, M. A., Keller, S., et al. (2009). Fungal entomopathogens: new insights in their ecology. Fung. Ecol. 2, 149-159.

Verhagen, B. W. M., Glazebrook, J., Zhu, T., Chang, H. S., van Loon, L. C., and Pieterse, C. M. J. (2004). The transcriptome of rhizobacteriainduced systemic resistance in Arabidopsis. Mol. Plant Microbe Interact. 17, 895-908.
Walker, V., Couillerot, O., Von Felten, A., Bellvert, F., Jansa, J., Maurhofer M., et al. (2012). Variation of secondary metabolite levels in maize seedling roots induced by inoculation with Azospirillum, Pseudomonas and Glomus consortium under field conditions. Plant Soil 356, 151-163.

Weller, D. M., Landa, B. B., Mavrodi, O. V., Schroeder, K. L., De La Fuente, L., Bankhead, S. B., etal. (2007). Role of 2,4diacetylphloroglucinol-producing fluorescent Pseudomonas spp. in the defence of plant roots. Plant Biol. 9, 4-20.

Weller, D. M., Mavrodi, D. V., van Pelt, J. A., Pieterse, C. M. J., van Loon, L. C., and Bakker, P. (2012). Induced systemic resistance in Arabidopsis thaliana against Pseudomonas syringae pv. tomato by 2,4-diacetylphloroglucinol-producing Pseudomonas fluorescens. Phytopathology 102, 403-412.

Whipps, J. M. (2001). Microbial interactions and biocontrol in the rhizosphere. J. Exp. Bot. 52, 487-511.

Wicklow, D. T., and Poling, S. M. (2009). Antimicrobial activity of pyrrocidines from Acremonium zeae against endophytes and pathogens of maize. Phytopathology 99, 109-115.

Wu, F. Y., Wan, J. H. C., Wu, S. C., and Wong, M. H. (2012). Effects of earthworms and plant growth-promoting rhizobacteria (PGPR) on availability of nitrogen, phosphorus, and potassium in soil. J. Plant Nutr. Soil Sci. $175,423-433$.

Wurst, S. (2010). Effects of earthworms on above- and belowground herbivores. Appl. Soil Ecol. 45, 123-130.

Wurst, S., Langel, R., Rodger, S., and Scheu, S. (2006). Effects of belowground biota on primary and secondary metabolites in Bras sica oleracea. Chemoecology 16, 69-73.

Zamioudis, C., and Pieterse, C. M. J. (2012). Modulation of host immunity by beneficial microbes. Mol. Plant Microbe Interact. 25, 139-150.

Zhang, P. J., Broekgaarden, C., Zheng, S. J., Snoeren, T. A., van Loon, J. J., Gols, R., et al. (2013). Jasmonate and ethylene signaling mediate whiteflyinduced interference with indirect plant defence in Arabidopsis thaliana. New Phytol. 197, 12911299.

Conflict of Interest Statement: The authors declare that the research was conducted in the absence of any commercial or financial relationships that could be construed as a potential conflict of interest.

Received: 31 December 2012; accepted: 19 March 2013; published online: 10 April 2013.

Citation: Hol WHG, Bezemer TM and Biere A (2013) Getting the ecology into interactions between plants and the plant growth-promoting bacterium Pseudomonas fluorescens. Front. Plant Sci. 4:81. doi: 10.3389/fpls.2013.00081

This article was submitted to Frontiers in Plant-Microbe Interaction, a specialty of Frontiers in Plant Science.

Copyright (C) 2013 Hol, Bezemer and Biere. This is an open-access article distributed under the terms of the Creative Commons Attribution License, which permits use, distribution and reproduction in other forums, provided the original authors and source are credited and subject to any copyright notices concerning any third-party graphics etc. 